\title{
Establishment of a regional centre for DNA-barcoding of rare and endangered plant species based on the DNA bank of the Republic of Belarus
}

\author{
N. Savina ${ }^{1 *}$, S. Kubrak ${ }^{1}$, E. Kuzminova ${ }^{1}$, E. Mikhalenko ${ }^{1}$, L. Milko ${ }^{1}$, A. Kolbas ${ }^{2}$, \\ N. Matusevich ${ }^{2}$, E. Makeyeva ${ }^{1}$, A. Kilchevskiy ${ }^{1}$ \\ ${ }^{1}$ Institute of Genetics and Cytology NASB, Minsk, Belarus \\ ${ }^{2}$ Brest State University named after A.S. Pushkin, Brest, Belarus \\ *e-mail:N.Savina@igc.by
}

Key words: DNA-barcoding, ITS2, rbcL, psbA-trnH

Motivation and Aim: Rare and endangered plant species are characterized by a lower ability to survive in the face of climate change and the pressure of anthropogenic factors, leading to loss of valuable genotypes and a decrease in biodiversity in general. In view of this, a unit "DNA Bank of Rare and Endangered Species of Wild Flora and Fauna" was established at the Republican DNA Bank of a human, animals, plants and microorganisms for comprehensive study and conservation of biological diversity of rare and endangered species listed in the Red Book of the Republic of Belarus.

Methods and Algorithms: The employees of Brest State University collect biomaterial of rare plants and compile a Database "Cartographic Web-application of rare plants' populations in Brest Region" that contains a morphological, ecological and geographic description of every plant [1]. The staff of the Institute of Genetics and Cytology, NAS of Belarus, perform identification of the collected material using a DNA-barcoding technique. The information obtained is entered in the Database of the Republican DNA Bank of a human, animals, plants and microorganisms.

Results: To date, 35 rare and endangered plant species (I-IV protection categories) collected in the National Parks "Narochansky" and "Belovezhskaya Pushcha" have been examined. DNA-barcoding was carried out using ITS2, rbcL, psbA-trnH marker sequences. The resolving power of $\mathrm{rbcL}$ and $\mathrm{psbA}-\operatorname{trnH}$ chloroplast markers proved insufficient for independent use as barcodes. At the same time, the use of ITS2 nuclear region significantly increased the efficacy of species identification of rare plants both for independent use and along with rbcL and psbA-trnH markers.

Conclusion: The obtained results allow to use DNA-barcoding as an ecologic monitoring tool for wildlife and in nature conservation activity. It is planned to hold a training course for Central and Eastern Europe and Central Asia's specialists on DNA-barcoding use and to establish a Regional Centre for DNA-barcoding of rare and endangered plant species. Acknowledgements: Supported by the Presidium of NASB (No. 629 of August 13, 2016). References

1. http://arcg.is/2hssjpw . 